\title{
PELAKSANAAN HAK POLITIK PEMILIH DISABILITAS DALAM PEMILU SERENTAK TAHUN 2019 DI KABUPATEN TANAH DATAR MENURUT UNDANG-UNDANG DISABILITAS DAN FIQH SIYASAH DUSTURIYAH
}

\author{
Marlindawati ${ }^{1}$, Ulya Atsani² \\ ${ }^{1}$ Institut Agama Islam Negeri Batusangkar \\ e-mail: watimarlinda07@gmail.com \\ 2Institut Agama Islam Negeri Batusangkar \\ ulyaatsani@iainbatusangkar.ac.id
}

\begin{abstract}
This study discusses the implementation of the political rights of disability voters in the 2019 simultaneous elections in Tanah Datar District according to the Disability and Fiqh Law Siyasah Dusturiyah. This type of research is field research in which materials are collected through interviews and documentation. The method used is a sociological juridical research method. Theories used are general election theory, political rights theory, disability political rights theory and siyasah dusturiyah figh theory. From the results of the research that the author did, it can be concluded that the implementation of fulfilling the political rights of persons with disabilities in the 2019 Simultaneous Elections in Tanah Datar District has not been carried out optimally. The obstacle faced by KPU in implementing the political rights of persons with disabilities is the difficulty in providing socialization to persons with disabilities. A review of figh siyasah dusturiyah on the implementation of the political rights of persons with disabilities was carried out by the Ablu Halli Wal Aqdi institution which is an institution to accommodate the aspirations of the people. The fulfillment of political rights of persons with disabilities in the election is not in accordance with the fiqh siyasah dusturiyah.
\end{abstract}

Keywords: Hak Politik Disabilitas, Pemilu Serentak, Fiqh Siyasah Dusturiyah.

\section{PENDAHULUAN}

Hak asasi manusia (HAM) sebagai hak dasar yang dimiliki dan melekat pada diri setiap manusia sepanjang hidupnya. Hak dasar yang dimiliki oleh setiap individu tanpa terkecuali kemudian menuntut kepada setiap individu untuk melaksanakan atau mendapatkan hak tersebut tanpa membentur hak orang lain. Sebagai hak dasar, hak asasi manusia memiliki lingkup yang sangat luas. Sebuah pengakuan terhadap ham dapat dikatakan sempurna apabila dalam wujud penghormatannya, pembelaannya, perlindungan, dan penjaminannya terhadap terpenuhinya hak asasi manusia berlangsung dengan tidak adanya diskriminasi. (Pawesti, 2017: 167).

Wujud dari pemenuhan hak-hak politik adalah adanya kebebasan bagi setiap warga untuk menyatakan pendapat dan berkumpul. Seperti yang tertuang dalam UUD 1945 pasal 28: "kemerdekaan berserikat dan berkumpul mengeluarkan pikiran dengan lisan dan tulisan dan sebagainya ditetapkan dengan undang-undang". Setiap orang memiliki hak yang sama untuk ikut berpartisipasi dalam pemerintahan, dimana hak tersebut merupakan bagian dari hak asasi manusia sebagaimana diatur dalam UUD Negara Republik Indonesia Tahun 1945.

Dalam konsepsi negara hukum yang demokratis, setiap warga negara kedudukannya sama untuk ikut serta berpartisipasi dalam pemerintahan termasuk didalamnya bagi para penyandang disabilitas. Pasal 13 Undang-Undang Nomor 8 Tahun 2016 tentang Penyandang 
Disabilitas menyebutkan, bahwa hak-hak politik bagi penyandang disabilitas meliputi: hak memilih dan dipilih dalam jabatan publik, menyalurkan aspirasi politik baik tertulis maupun lisan, memilih partai politik atau individu yang menjadi peserta dalam pemilihan umum, membentuk serta menjadi anggota atau pengurus organisasi masyarakat atau partai politik, membentuk dan bergabung dalam organisasi penyandang disabilitas serta aktif mewakili penyandang disabilitas dalam tingkat lokal hingga tingkat internasional, berperan serta aktif dalam sistem pemilihan umum, memperoleh aksesibilitas pada sarana dan prasarana pemilihan umum, serta memperoleh pendidikan politik. (Undang-Undang Nomor 8 Tahun 2016).

Berdasarkan data Komisi Pemilihan Umum Kabupaten Tanah Datar jumlah seluruh pemilih disabilitas terdaftar dalam DPT,DPTb, dan DPK adalah 910 terdiri dari 414 laki-laki dan 496 perempuan. Sedangkan jumlah seluruh pemilih disabilitas yang menggunakan hak pilih adalah 453 terdiri dari 181 laki-laki dan 272 perempuan.Yang bisa dilihat pada tabel berikut:

Tabel 1.1

Pemilih Disabilitas Di Tanah Datar

\begin{tabular}{|c|c|c|c|c|c|c|c|}
\hline \multirow[t]{2}{*}{ No } & \multirow[t]{2}{*}{$\begin{array}{c}\text { Data Pemilih } \\
\text { Disabilitas } \\
\text { Kecamatan }\end{array}$} & \multicolumn{2}{|c|}{$\begin{array}{c}\text { Jumlah Seluruh } \\
\text { Pemilih Disabilitas } \\
\text { TerdaftarDalam DPP. } \\
\text { DPtb Dan DPK }\end{array}$} & \multirow[t]{2}{*}{$\begin{array}{l}\text { Juml } \\
\text { ah } \\
\text { LK/P } \\
\text { R }\end{array}$} & \multicolumn{2}{|c|}{$\begin{array}{c}\text { Jumlah Seluruh } \\
\text { Pemilih } \\
\text { DisabilitasYang } \\
\text { Menggunakan } \\
\text { Hak Pilih }\end{array}$} & \multirow[t]{2}{*}{$\begin{array}{l}\text { Jumlah } \\
\text { LK/PR }\end{array}$} \\
\hline & & LK & PR & & LK & PR & \\
\hline 1 & X Koto & 15 & 29 & 44 & 8 & 22 & 30 \\
\hline 2 & Batipuh & 7 & 13 & 20 & 5 & 11 & 16 \\
\hline 3 & Rambatan & 26 & 32 & 58 & 26 & 37 & 63 \\
\hline 4 & $\begin{array}{l}\text { Lima } \\
\text { Kaum }\end{array}$ & 31 & 53 & 84 & 25 & 42 & 67 \\
\hline 5 & TanjungEmas & 22 & 35 & 57 & 21 & 35 & 56 \\
\hline 6 & Lintau Buo & 105 & 115 & 220 & 15 & 5 & 23 \\
\hline 7 & Sungayang & 19 & 18 & 37 & 14 & 8 & 27 \\
\hline 8 & SungaiTarab & 121 & 94 & 215 & 10 & 6 & 16 \\
\hline 9 & Pariangan & 10 & 31 & 41 & 8 & 30 & 38 \\
\hline 10 & Salimpaung & 11 & 19 & 29 & 8 & 16 & 24 \\
\hline 11 & $\begin{array}{l}\text { Padang } \\
\text { Ganting }\end{array}$ & 2 & 20 & 27 & 6 & 18 & 24 \\
\hline 12 & TanjungBaru & 15 & 20 & 35 & 11 & 16 & 27 \\
\hline 13 & LintauBuoUtara & 18 & 10 & 28 & 18 & 12 & 30 \\
\hline 14 & BatipuahSelatan & 7 & 7 & 14 & 6 & 6 & 12 \\
\hline & Jumlah & 414 & 496 & 910 & 181 & 272 & 453 \\
\hline
\end{tabular}

Berdasarkan survei awal yang penulis lakukan di Komisi Pemilihan Umum (KPU) Kabupaten Tanah Datar dapat dilihat dari hasil Pemilu di tiap Kecamatan terhadap pelaksanaan hak politik penyandang disabilitas dalam Pemilu serentak 2019 terlihat masih rendahnya partisipasi politik penyandang disabilitas.

Seperti di Kecamatan Sungai Tarab tingkat partisipasi politik penyandang disabilitas terlihat sangat rendah. Berdasarkan data dari Komisi Pemilihan Umum (KPU) jumlah seluruh pemilih disabilitas adalah sebanyak 215 orang sedangkan yang menggunakan hak pilihnya 
hanya 16 orang atau sekitar 7\%. Oleh karena itu penulis tertarik ingin melihat bagaimana pelaksanaan hak politik disabilitas pada pemilu serentak Tahun2019 di Kabupaten Tanah Datar.

Berdasarkan permasalahan yang telah dipaparkan di atas penyusun tertarik untuk melakukan penelitian lebih lanjut mengenai Pelaksanaan Hak Politik Pemilih Disabilitas Dalam Pemilu Serentak 2019 Di Kabupaten Tanah Datar Menurut Undang-Undang Disabilitas dan Fiqh Siyasah Dusturiyah.

\section{METODE PENELITIAN}

Jenis penelitian yang digunakan dalam penulisan skripsi ini adalah penelitian lapangan (field research) yaitu penelitian dengan cara mengumpulkan bahan-bahan yang berasal dari wawancara dan dokumentasi yang berkaitan dengan masalah yang diangkat. Penulis menggunakan metode penelitian yuridis sosiologis untuk meneliti dan membahas skripsi ini. Dalam hal ini penulis menggunakan UU Nomor 8 Tahun 2016 sebagai acuan utamanya. Di samping itu, karena teori utama dalam sripsi ini adalah Fiqh Siyasah Dusturiyah, maka penulis menggunakan metode kajian fikih dengan menggunakan dalil-dalil, baik Alqur'an mapun Hadis, kemudian menarik kesimpulan hukum dari dalil- dalil tersebut.

\section{HASIL DAN PEMBAHASAN}

Sulthah tasyri'iyyah merupakan kekuasaan legislatif yang meliputi persoalan persoalan ahlu hali wal aqdi, perwakilan persoalan rakyat. Hubungan muslimin dan non-muslim di dalam suatu negara, seperti undang-undang dasar, undang-undang, peraturan pelaksana, peraturan daerah.

a. Ahlul Halii Wal Aqdi

Dalam fiqhsiyasahlembaga yang betugas untuk pemenuhan hak-hak politik rakyat adalah Ahlul Halii Wal Aqdi. Selain sebagai panitia penyelenggara pemilihan khalifah, lembaga Ahlul Halii Wal Aqdi atau al- syura meiliki tugas dan kewengan untuk memberikan masukan kepada khalifah, sebagai lembaga yang menampung aspirasi masyarakat, melakukan controlling terhadap kebijakan-kebijakan pemerintah,membuat undang-undang sekaligus mempunyai hak untuk mebatasi jumlah kandidat yang akan menjadi pemimpin.

Kajian terhadap Ahlul Halii Wal Aqdi memberikan gambaran, bahwa kewenangan AhlulHaliiWalAqdimemiliki kesamaan dengan kewenangan Komisi Pemilihan Umum terkait pemenuhan hak politik rakyatnya (Djazuli, 2003: 33).

b. Pemilihan Umum (Pemilu)

Pemilu merupakan salah satu pilar demokrasi sebagai sarana perwujudan kedaulatan rakyat guna menghasilkan pemerintahan yang demokratis. Pemerintahan yang dihasilkan dari Pemilu diharapkan menjadi pemerintahan yang mendapat legitimasi yang kuat dan amanah. Pemilu pun menjadi tonggak tegaknya demokrasi, di mana rakyat secara langsung terlibat aktif dalam menentukan arah dan kebijakan politik negara untuk satu periode pemerintahan ke depan. (Rahman, 2019)

Pelaksanaan Pemilu di Indonesia menganut asas 'Luber" yang merupakan singkatan dari “Langsung. Umum, Bebas, dan Rahasia. Asas “Luber sudah ada sejak zaman Orde Baru. 
Kemudian pada era Reformasi berkembang pula asas "Jurdil" yang merupakan singkatan dari "Jujur dan Adil".

c. Hak politik

Hak politik warga negara mencakup hak untuk memilih dan dipilih, penjaminan hakdipilih secara tersurat dalam UUD 1945 mulai Pasal 27 ayat (1) dan (2); Pasal 28,Pasal 28D ayat (3); Pasal 28E ayat (3).56Sementara hak memilih juga diatur dalamPasal 1 ayat (2); Pasal 2 ayat (1); Pasal 6A ayat (1); Pasal 19 ayat (1) dan Pasal 22Cayat (1) UUD 1945

d. Hak politik disabilitas

Dalam Pasal 13 Undang-Undang Nomor 8 Tahun 2016 tentang Penyandang Disabilitas menyebutkan bahwa hak-hak politik bagi penyandang disabilitas meliputi hak memilih dan dipilih dalam jabatan publik, menyalurkan aspirasi politik baik tertulis maupun lisan, memilih partai politik atau individu yang menjadi peserta dalam pemilihan umum, membentuk serta menjadi anggota atau pengurus organisasi masyarakat atau partai politik, membentuk dan bergabung dalam organisasi penyandang disabilitas serta aktif mewakili penyandang disabilitas dalam tingkat lokal hingga tingkat internasional, berperan serta aktif dalam sistem pemilihan umum, memperoleh aksesibilitas pada sarana dan prasarana pemilihan umum, serta memperoleh pendidikan politik.

e. Fiqh siyasah dusturiyah

Siyasah dusturiyah adalah bagian fiqh siyasah yang membahas masalah perundangundangan negara. Dalam hal ini juga dibahas antara lain konsep-konsep konstitusi (undangundang dasar negara dan sejarah lahirnya perundang-undangan dalam suatu negara), legislasi (bagaimana cara perumusan undang-undang), lembaga demokrasi dan syura yang merupakan pilar penting dalam perundang-undangan tersebut. Di samping itu, kajian ini juga membahas konsep negara hukum dalam siyasah dan hubungan timbal balik antara pemerintah dan warga negara serta hak-hak warga negara yang wajib dilindungi. (Iqbal, 2014: 177)

\section{A. Pemenuhan Hak Politik Penyandang Disabilitas dalam Pemilu Serentak Tahun 2019 di Kabupaten Tanah Datar}

Pemilihan Umum (Pemilu) merupakan salah satu akses bagi warga negara untuk menyalurkan hak dan partisipasi politiknya. Pemilu yang sering disebut sebagai pesta demokrasi masyarakat harus melibatkan semua elemen dan lapisan warga negara tanpa terkecuali. Salah satu indikator penyelenggaraan Pemilu yang berkualitas adalah unsur-unsur partisipasi masyarakat.

Inti dari penyelenggaraan Pemilu adalah bentuk perwujudan dari kedaulatan rakyat atau warga negara dalam menentukan bentuk pemerintahan kedepannya. Dalam hal ini warga negara tanpa terkecuali mempunyai hak dalam proses politik.

Hak politik sebagai serangkaian hak yang dimiliki oleh setiap individu tanpa terkecuali. Hak-hak yang terkandung dalam hak politik, pada dasarnya merupakan hak warga negara untuk ikut berperan dalam pemerintahan. Pokok dari hak dan kewajiban politik warga negara sebagaimana dijelaskan dalam Pasal 27 ayat (1) Undang- Undang Dasar 1945 menyebutkan bahwa "setiap warga negara memiliki kedudukan yang sama dalam hukum dan pemerintahan dan wajib menjunjung tinggi hukum dan pemerintahan negara tanpa terkecuali"

Berdasarkan Undang-Undang Nomor 8 Tahun 2016, Pasal 13 yaitu:

Hak politik untuk Penyandang Disabilitas meliputi hak:

1. Memilih dan dipilih dalam jabatan publik; 
2. Menyalurkan aspirasi politik baik tertulis maupun lisan;

3. Memilih partai politik dan/atau individu yang menjadi peserta dalam pemilihan umum;

4. Membentuk, menjadi anggota, dan/atau pengurus organisasi masyarakat dan/atau partai politik;

5. Membentuk dan bergabung dalam organisasi Penyandang Disabilitas dan untuk mewakili Penyandang Disabilitas pada tingkat lokal, nasional, dan internasional;

6. Berperan serta secara aktif dalam sistem pemilihan umum pada semua tahap dan/atau bagian penyelenggaraannya;

7. Memperoleh Aksesibilitas pada sarana dan prasarana penyelenggaraan pemilihan umum, pemilihan gubernur, bupati/walikota, dan pemilihan kepala desa atau nama lain; dan

8. Memperoleh pendidikan politik.

Berdasarkan wawancara yang Penulis lakukan dengan Bapak Fahrul Rozi S.Pd.i selaku Ketua Komisi Pemilihan Umum (KPU) Kabupaten Tanah Datar, tentang pemenuhan hak politik penyandang disabilitas beliau mengatakan: kalau untuk pelaksanaan Pemilu serentak alhamdulillah telah dilaksanakan sesuai dengan peraturan perundang-undangan yang berlaku, dan sudah menghasilkan output ataupun tujuan dari pemilu itu sendiri. Untuk pemilihan anggota DPRD Kabupaten sudah terpilih calon ataupun wakil rakyat dari masing-masing dapil. Begitu juga dengan anggota DPR-RI, DPRD Prov, DPD dan sekaligus pemilihan Presiden dan Wakil Presiden di Kabupaten Tanah Datar. Kalau pelaksanaannya mulai dari TPS sampai Rekapitulasi di Kecamatan, Kabupaten, sampai tingkat provinsi berjalan lancar. Untuk pemenuhan hak politik penyandang disabilitas dalam UU No 7 Tahun 2017 sudah diatur bahwasannya, bagi warga negara Indonesia yang disabilitas memiliki hak untuk memilih ataupun untuk menjadi peserta dan penyelenggara Pemilu.

Kalau di Kabupaten Tanah Datar tentunya warga disabilitas yang memiliki hak pilih kita fasilitasi dan itu telah dilakukan, artinya dalam pendataan pemilih di masing-masing nagari ataupun TPS itu sudah kita data warga yang tergolong disabilitas agar mereka memiliki hak pilih dalam pemilu serentak tahun 2019. Kemaren itu mereka sudah menyalurkan hak pilihnya ada yang tuna runggu,tuna daksa dan seperti yang kurang penglihatan, kurang pendengarannya dan lain-lain itu kita fasilitasi.

Fasilitasi yang kita berikan seperti alat bantu untuk yang kurang penglihatannya dan sudah diberikan kepada tiap-tiap TPS. Dan untuk yang kurang pendengaran dan segala macamnya petugas KPPS yang akan membantu dalam menyalurkan hak pilihnya. Dan untuk pemilih yang lumpuh kita tetap menghadirkan yang bersangkutan untuk datang ke TPS dan caranya yang pertama jika mereka berada di luar TPS tentunya kita dahulukan untuk menyalurkan hak pilihnya.

Kedua dibantu oleh petugas KPPS untuk masuk kedalam bilik suara. Contohnya para disabilitas tuna daksa untuk memilih mereka masih bisa menentukan pilihannya sesuai dengan hati nuraninya, dan petugas hanya mengarahkan saja dan membantu untuk masuk kebilik suara dengan tidak didampingi oleh petugas KPPS agar azas kerahasiaan dalam pemilu tetap terjaga (wawancara dengan Bapak Ketua Komisi Pemilihan Umum Kabupaten Tanah Datar Fahrul Rozi S.Pd.i, Tanggal 05 Juni 2020 Jam 10.00 WIB). 
Selanjutnya penulis mewawancarai Sekretaris KPU Bapak Sonata SE beliau mengatakan, terkait pemenuhan hak politik disabilitas dalam pemilu serentak di Kabupaten Tanah Datar pertama tentu kami melakukan sosialisasi kepada Panitia Pemilihan Kecamatan (PPK) agar mensosialisasikan kembali kepada Panitia Pemungutan Suara (PPS) agar pemilu serentak ini dapat berjalan dengan lancar. Dan tidak lupa agar memberikan sosialisasi kepada penyandang disabilitas.(Wawancara dengan Bapak Sekretaris KPU Sonata SE, Tanggal 05 Juni 2020, Jam 11. 00 WIB).

Selanjutnya penulis mewawancarai Komisioner KPU bidang sosialisasi, pendidikan pemilih, dan partisipasi masyarakat Bapak Thomas Hendriko S.Pd.i terkait pemenuhan hak politik penyandang disabilitas dalam Pemilu serentak Tahun 2019 di Kabupaten Tanah Datar beliau mengatakan, dalam hal pemenuhan hak politik kita melakukan pembedaan antara pemilih disabilitas dengan pemilih biasanya. Kita memberikan kesempatan kepada merekauntuk menjadi penyelenggara pemilu seperti menjadi anggota PPK, PPS maupun KPPS.

Bahkan kemarin ada ada satu orang PPS di Lintau yang disabilitas dan itu kita berikan kesempatan bagi mereka dan juga sebagai pemilih. Terhadap disabilitas tidak ada diskrimasinya dan sama dengan masyarakat pada umumnya (Wawancara dengan Bapak Komisioner KPU Thomas Hendriko S.Pd.i, Tanggal 06 Juni 2020, Jam 14.00 WIB).

Selanjutnya, penulis mewawancarai ketua Panitia Pemilihan Kecamatan (PPK) Sungai Tarab Bapak Angga Gunawan terkait pemenuhan hak politik penyandang disabilitas dalam pemilu serentak tahun 2019 di Kabupaten Tanah Datar beliau mengatakan, untuk terselenggaranya pemilu serentak tahun 2019, kami telah membentuk Panitia Pemungutan Suara (PPS), Kemudian PPS membentuk PPDP untuk melakukan pendataan terhadap para pemilih pemilu yang mana PPS akan mensosialisasikan kepada masyarakat akan pentingnya pemilu, tetapi dalam pelaksanaan sosialisasi ini petugas agak mengalami kesulitan dalam penyampaian materi. (Wawancara dengan ketua panitia pemilihan kecamatan Sungai Tarab Bapak Angga Gunawan, Tanggal 08 Juni 2020, Jam 16. 30 WIB).

Selanjutrnya, penulis mewawancarai ketua Panitia Pemungutan Suara (PPS) Sungai Tarab Bapak Yuto Himarkoling, beliau mengatakan, terkait pemenuhan hak politik disabilitas dalam pemilu serentak di Kabupaten Tanah Datar, sebagai penyelenggara pemilu dalam pemilu serentak Tahun 2019 kami melakukan pendataan terlebih dahulu dari rumah kerumah, serta melakukan sosialisi langsung kepada masyarakat, (Wawancara dengan ketua Panitia Pemilihan Kecamatan (PPK) Sungai Tarab Bapak Yuto Himarkoling, Tanggal 08 Juni 2020, Jam 14.00 WIB).

Selanjutnya penulis mewawancarai Bapak Nasrul penyandang disabilitas tuna rungu pemilih, terkait pemenuhan hak poilitik disabilitas. Belum maksimalnya upaya dan program dari KPU yang belum bisa memberikan pelayanan kepada penyandang disabilitas khususnya tuna rungu sehingga harus mengikuti antrian yang panjang bersama masyarakat non disabilitas. Karena dianggap mampu dan tidak ada kendala.

Wawancara yang penulis lakukan dengan Bapak Nasrul selaku tuna daksa mengatakan: dalam pelaksanaan pemilu serentak saya penyandang disabilitas, dalam menyalurkan hak pilih masih ikut mengantri dengan masyarakat non disabilitas, tidak ada perlakuan khusus oleh TPS (wawancara dengan Bapak Nasrul selaku penyandang disabilitas tuna rungu, Tanggal 01 Juni 2020 Jam 14.00 WIB)

Pendapat yang serupa juga disampaikan oleh Bapak Hendrizal penyandang disabilitas tuna daksa, mengenai pemenuhan hak politik disabilitas saat pemilihan. Beliau mengatakan: 
kami ada mendapatkan sosialisasi dari Panitia Pemungutan Suara (PPS) tetapi dalam penyampaian materinya kami tidak memahami dikarenakan bahasa yang digunakan petugas terlalu tinggi. Apalagi kami penyandang disabilitas tuna daksa, dan juga akses untuk menuju TPS sangat sulit sekali (wawancara dengan Bapak Hendrizal selaku penyandang disabilitas tuna daksa, Tanggal 01 Juni 2020 Jam 10.00 WIB).

Berdasarkan keterangan yang penulis temui dilapangan terkait pemenuhan hak politik penyandang disabilitas dalam pemilu serentak Tahun 2019 di Kabupaten Tanah Datar di Kecamatan Sungai Tarab belum terpenuhi sebagaimana mestinya sesuai dengan PKPU Nomor 10 Tahun 2018 tentang sosialisasi, pendidikan pemilih dan partisipasi masyarakat dalam penyelenggaraan pemilihan umum.

Selanjutnya penulis mewawancarai Ibu Rosmaidar selaku penyandang disabilitas tuna daksa , terkait pemenuhan hak politik penyandang disabilitas dalam Pemilu sentak tahun 2019, beliau mengatakan, saya disabilitas tuna daksa masih kesulitan dalam melakukan pencoblosan pada saat pemilu, dikarenakan sewaktu mencoblos saya tidak ada pendampingan untuk datang ke TPS, petugas TPS jua tidak ada memberikan arahan dan perlakuaan khusus terhadap kami selaku penyandang disabilitas(wawancara dengan Ibu Rosmaidar selaku penyandang disabilitas tuna daksa, Tanggal 02 Juni 2020 Jam 10.30 WIB).

Selanjutnya penulis mewawancarai Bapak Gusrial selaku penyandang disabilitas tuna netra, terkait pemenuhan hak politik penyandang disabilitas dalam pemilu serentak tahun 2019 di Kabupaten Tanah Datar, beliau mengatakan, pada pemilu kemaren saya disabilitas tuna netra merasa agak sulit berpartisipasi dalam pemilu. Karena saya tidak mengetahui tata cara pemberian suara bagi para penyandang disabilitas. Serta saya juga tidak ada diberikan sosialisasi oleh para petugas penyelenggara pemilu. Oleh karena itu sangat saya merasa tidak diberi kemudahan dalam menyalurkan hak pilih.(wawancara dengan Bapak Gusrial selaku penyandang disabilitas tuna netra, tanggal 3 Juni 2020 Jam 11.00 WIB)

Dengan demikian penulis dapat melihat bahwa pemenuhan hak politik bagi penyandang disabilitas di Kabupaten Tanah Datar belum terpenuhi secara keseluruhan. Dimana pada Pemilu serentak Tahun 2019 Komisi Pemilihan Umum tidak efektif dalam memberikan pendidikan politik kepada pemilih disabilitas pada tiap- tiap Kecamatan yang ada di Kabupaten Tanah Datar.

Sebagaimana yang dijelaskan dalam Undang-Undang Nomor 8 Tahun 2016 tentang penyandang disabilitas, seharusnya Komisi Pemilihan Umum tidak hanya memberikan pendidikan politik kepada masyarakat umum (non disabilitas) tetapi juga harus memberikan pendidikan politik kepada para pemilih disabilitas.

Komisi Pemilihan Umum juga harus memiliki cara dan strategi yang berbeda dalam memeberikan pendidikan politik bagi penyandang disabilitas dan memberikan akses yang mudah untuk penyandang disabilitas menuju TPS sesuai dengan PKPU Nomor 15 Tahun 2018 tentang Norma, Standar, Prosedur, Kebutuhan Pengadaan Dan Pendistribusian Perlengkapan Penyelenggaraan Pemilihan Umum.

\section{B. Kendala Komisi Pemilihan Umum dalam Pemenuhan Hak Politik Penyandang Disabilitas Dalam Pemilu Serentak 2019}

Meningkatkan partisipasi penyandang disabilitas dalam rangka pemenuhan hak politiknya dalam Pemilu tentunya tidaklah mudah. Untuk KPU Kabupaten Tanah Datar telah melakukan segala upaya untuk menjamin terpenuhinya hak politik penyandang disabilitas yang 
diharapkan dapat terciptanya pemilu yang inklusif. Adapun beberapa upaya dan kendala yang dihadapi Komisi Pemilihan Umum (KPU) dalam melaksanakan pemenuhan hak politik disabilitas ini.

Wawancara yang penulis lakukan dengan Bapak Ketua Komisi Pemilihan Umum (KPU) Kabupaten Tanah Datar Bapak Fahrul Rozi S.Pd.I terkait faktor pendorong dan kendala yang dihadapi oleh Komisi Pemilihan Umum (KPU) dalam Pemilihan serentak tahun 2019 beliau mengatakan, dalam rangka menghapus diskriminasi dan pemberian kesempatan yang sama dalam pemilihan umum serentak tahun 2019 kami memberikan kesempatan yang sama kepada para penyandang disabilitas untuk menjadi penyelenggara dalam Pemilihan Umum. Kemudian memberikan bimbingan teknis secara berjenjang mulai dari PPK, PPS, dan KPPS terkait pelayanan yang harus dilakukan di TPS dan tugas-tugas petugas penyelenggara Pemilu.

Terhadap kendala yang kami temui dalam pemenuhan hak politik penyandang disabilitas kalausecara umum tidak ada. Tapi di Tanah Datar mungkin yang agak menyulitkan dalam pemberian sosialisasi. Karena di Kabupaten Tanah Datar tidak ada organisasi disabilitas yang dapat dijadikan wadah bagi penyelenggara untuk berhubungan dengan kelompok penyandang disabilitas. Sehingga pihak penyelenggara pemilu dalam hal ini KPU Kabupaten Tanah Datar kesulitan dalam mengorganisir penyandang disabilitas (wawancara dengan Ketua Komisi Pemilihan Umum (KPU) Kabupaten Tanah Datar, Tanggal 05 Juni 2020, Jam 10.00 WIB).

Selanjutnya penulis mewawancarai Bapak Thomas Hendriko selaku Komisioner KPU Kabupaten Tanah Datar bidang sosialisasi,pendidikan pemilih, dan partisipasi masyarakat terkait upaya ataupun faktor pendorong dan kendala yang di hadapi Komisi Pemilihan Umum (KPU) dalam pemenuhan hak politik disabilitas dalam pemilu serentak 2019 beliau mengatakan: dalam pemenuhan hak politik penyandang disabilitas kami dari pihak KPU telah melaksanakan beberapa upaya agar terpenuhinya hak politik penyandang disabilitas.

Pertama kami mengadakan sosialisasi pemilu kepada para pennyandang disabilitas. Sosialisasi ini merupakan salah satu bentuk upaya yang dilakukan oleh KPU Kabupaten Tanah Datar untuk memenuhi hak politik penyandang disabilitas. Dan sosialisasi yang kami lakukan terhadap penyandang disabilitas sekaligus memberikan pendidikan politik para penyandang disabilitas.

Kedua kami telah membentuk relawan demokrasi bertujuan untuk meningkatkan partisipasi penyandang disabilitas dalam menggunakan hak pilihnya.relawan demokrasi ini menjadi rekan KPU Tanah Datar dalam melakukan sosialisasi dan pendidikan politik bagi para penyandang disabilitas.

Mengenai kendala yang di hadapi oleh KPU dalam memenuhi hak politik disabilitas pertama petugas PPDP mengalami kesulitan dalam pendataan dikarenakan lokasi tempat tinggal penyandang disabilitas sulit untuk di jangkau seperti di daerah Talang Dasun akses menuju ke daerah tersebut masih di bilang sulit karena berada di daerah perbukitan sehingga tidak semua penyandang disabilitas dapat terdata seluruhnya.

Kedua dalam pelaksanaan sosialisasi, mengalami kesulitan dalam mentransfer materi kepada penyandang disabilitas dan membutuhkan metode khusus untuk menyampaikannya. Ditambah kurangnya pemahaman dari pihak keluarga penyandang disabilitas yang beranggapan kalau keluarganya yang disabilitas tersebut tidak berhak memilih sehingga ini juga menyulitkan petugas PPDP dalam melakukan pendataan (Wawancara dengan Bapak Komisioner KPU Thomas Hendriko S.Pd.I, Tanggal 05 Juni 2020, Jam 14.00 WIB). 
Selanjutnya penulis mewawancarai Sekretaris Komisi Pemilihan Umum Bapak Sonata SE, terkait factor pendorong dan kendala yang dihadai oleh Komisi Pemilihan Umum (KPU) dalam pemenuhan hak politik disabilitas beliau mengatakan, untuk menjamin terpenuhinya hak politik penyandang disabilitas di Kabupaten Tanah Datar kami telah menyediakan aksesibilitas untuk para pemilih disabilitas.

Adapun aksesibilitas yang kami berikan kepada pemilih disabilitas diantaranya, menyediakan braile template (alat bantu coblos) untuk penyandang disabilitas tuna netra, membuat regulasi mengenai TPS akses yang harus dibuat oleh petugas TPS di hari pemungutan suara, mengatur mengenai pendampingan untuk para penyandang disabilitas pada saat menggunakan hak suaranya, agar hak suara mereka tetap terjaga kerahasiaannya. Segala upaya yang kami lakukan dalam memenuhi hak politik penyandang disabilitas ini tidak lain untuk memudahkan para penyandang disabilitas menggunakan hak suaranya dalam Pemilu serentak tahun 2019 di Kabupaten Tanah Datar.

Mengenai hambatan yang kami temui di dalam pemenuhan hak politik penyandang disabilitas adalah tentang pendataan pemilih disabilitas.Karena tidak adanya data yang valid terhadap jumlah pemilih yang disabilitas sehingga banyak dari penyandang disabilitas yang tidak terdata dan pada akhirnya tidak dapat menyalurkan hak suaranya dalam pemilu serentak tahun 2019 (wawancara dengan Sekretaris Komisi Pemilihan Umum Bapak Sonata SE, Tanggal 05 Juni 2020 Jam 11.00 WIB).

Berdasarkan hasil wawancara penulis dengan para narasumber dapat disimpulkan bahwasannya Komisi Pemilihan Umum (KPU) telah melakukan upaya dan program-program untuk memenuhi hak politik penyandang disabilitas. Dalam menjalankan program tersebut Komisi Pemilihan Umum (KPU) selaku penyelenggara pemilu juga menemui hambatan dan kendala- kendala sehingga hak politik penyandang disabilitas belum terpenuhi secara keseluruhan.

\section{Pemenuhan Hak Politik Penyandang Disabilitas Menurut Undang-Undang Disabilitas dan Fiqh Siyasah Dusturiyah}

\section{Tinjauan Undang-Undang Disabilitas}

Wujud dari pemenuhan hak-hak politik adalah adanya kebebasan bagi setiap warga untuk menyatakan pendapat dan berkumpul. Seperti yang tertuang dalam UUD 1945 pasal 28 yang berbunyi: "Kemerdekaan berserikat dan berkumpul mengeluarkan pikiran dengan lisan dan tulisan dan sebagainya ditetapkan dengan undang-undang".

Hal ini dipertegas kembali dalam Undang-undang, UU No. 39 Tahun 1999 tentang Hak Asasi Manusia mengatur tentang hak pilih dalam Pasal 43 yang menentukan bahwa "Setiap warga negara berhak untuk dipilih dan memilih dalam pemilihan umum berdasarkan persamaan hak melalui pemungutan suara yang langsung, umum, bebas, rahasia, jujur, dan adil sesuai dengan ketentuan peraturan perundang-undangan".

Dalam penjelasan undang-undang tersebut terlihat bahwa setiap orang memiliki hak dan kesempatan yang sama untuk ikut berpartisipasi dalam pemerintahan tanpa adanya diskriminasi serta berhak menyalurkan aspirasi dan pendapatnya tenpa terkecuali bagi para penyandang disabilitas. Penyandang disabilitas adalah orang yang memiliki keterbatasan fisik, mental, intelektual atau sensorik dalam jangka waktu lama yang dalam berinteraksi dengan lingkungan dan sikap masyarakatnya dapat menemui hambatan yang menyulitkan untuk berpartisipasi penuh dan efektif berdasarkan kesamaan hak, terkhusus dalam dunia perpolitikan 
yang telah di atur dalam (Undang-Undang Nomor 8 Tahun 2016 tentang hak-hak penyandang disabilitas).

Landasan kesetaraan bagi penyandang disabilitas memuat tentang kesamaan derajat bagi setiap orang dalam hukum dan pemerintahan yang diatur dalam Undang-Undang Dasar Negara Republik Indonesia Tahun 1945, di atur khusus dalam Pasal 27 yang menjelaskan bahwa "segala warga negara bersama kedudukannya didalam hukum dan pemerintahan dan wajib menjunjung hukum dan pemerintahan itu dengan tidak ada kecualinya".

Penyandang Disabilitas belum mendapat tempat di masyarakat. Kehadirannya masih dipandang sebelah mata. Keterbatasan yang dimiliki, membuat mereka dianggap sebagai kelompok yang lemah, tidak berdaya dan hanya perlu mendapatkan belas kasihan. Hak-hak mereka sebagai manusia seringkali diabaikan. Mulai dari hak untuk hidup, hak untuk memperoleh pelayanan pendidikan dan hak politik serta hak kemudahan mengakses fasilitas umum. (Widodo, 2019:19).

Penyandang disabilitas merupakan setiap orang yang memiliki hak untuk mendapat perlakuan khusus dari negara. Hal ini diatur dalam Pasal $28 \mathrm{H}$ yang menjelaskan bahwa setiap orang berhak mendapatkan kemudahan dan perlakuan khusus untuk memperoleh kesempatan dan manfaat yang sama guna mencapai persamaan dan keadilan.Setiap penyandang disabilitas mempunyai hak dan kesempatan yang sama dalam segala bidang kehidupan dan penghidupan. Oleh karena itu, hak-hak penyandang disabilitas harus dipenuhi agar dapat melaksanakan aktivitas tanpa adanya hambatan sebagaimana manusia seutuhnya tanpa kekurangan apapun. (Rita, 2016: 49).

Sebagaimana yang diatur dalam pasal 5 Undang-Undang Nomor 7 tahun 2017 tentang Pemilu menjelaskan "Penyandang disabilitas yang memenuhi syarat mempunyai kesempatan yang sama sebagai Pemilih, sebagai calon anggota DPR, sebagai calon anggota DPD, sebagai calon Presiden/Wakil Presiden, sebagai calon anggota DPRD, dan sebagai Penyelenggara Pemilu". (Undang-undang Nomor 7 Tahun 2017 tentang penyelenggaraan pemilu).

Dalam hal hak politik penyandang disabilitas, dalam pasal 13 huruf a Undang-Undang Nomor 8 Tahun 2016 Tentang penyandang disabilitas menyatakan bahwa penyandang disabilitas berhak dipilih dan memilih dalam jabatan publik. Dengan adanya ketentuan peraturan ini penyandang disabilitas di Indonesia memiliki landasan hukum yang kuat dalam perjuangan persamaan hak, baik dalam hal hak politik yang dimana penyandang disabilitas berhak dipilih dan memilih dalam jabatan publik. (Putra, 2019: 45)

Pemilu dapat dianggap memenuhi kriteria penguatan demokrasi jika mampu melindungi hak pilih disabiltas dan kemudahan aksesbilitas dalam pemilu. Bagi penyandang disabilitas akses dapat didefinisikan sebagai hak untuk berpartisipasi secara penuh tanpa halangan dan hambatan fisik maupun mental (Putra, 2019: 46). Dalam Pasal 13 huruf g menyatakan bahwa : "dalam penyelanggaraan pemilihan umum penyandang disabilitas berhak memperoleh aksesibilitas berupa sarana dan prasarana dalam pemilihan umum".

Berdasarkan PKPU Nomor 15 Tahun 2018 tentang Norma, Standar, Prosedur, Kebutuhan Pengadaan Dan Pendistribusian Perlengkapan Penyelenggaraan Pemilihan Umum Pasal 19 ayat (2): TPS/TPSLN sebagaimana yang dimaksud pada ayat (1) harus memberikan kemudahan akses bagi penyandang disabilitas. Selain itu dalam pasal 13 Undang-Undang Nomor 8 Tahun 2016 tentang Penyandang Disabilitas secara khusus juga menyatakan bahwa hak politik penyandang disabilitas meliputi: 
a. memilih dan dipilih dalam jabatan publik;

b. menyalurkan aspirasi politik baik tertulis maupun lisan;

c. memilih partai politik dan/atau individu yang menjadi peserta dalam pemilihan umum;

d. membentuk, menjadi anggota dan/atau pengurus organisasi masyarakat dan/atau partai politik.

e. membentuk dan bergabung dalam organisasi penyandang disabilitas dan untuk mewakili penyandang disabilitas pada tingkat lokal, nasional,daninternasional;

f. berperan serta secara efektif dalam sistem pemilihan umum pada semua tahap dan/atau bagianpenyelenggaraannya;

g. memperoleh aksesbilitas pada sarana dan prasarana penyelenggaraan pemilihan umum, pemilihan gubernur, bupati/walikota, dan pemilihan kepala desa atau nama lain; dan

h. memeperoleh pendidikan politik

Lebih lanjut Pasal 75 Undang-Undang Nomor 8 Tahun 2016 tentang Penyandang Disabilitas menyatakan bahwa:

a. pemerintah dan pemerintah daerah wajib menjamin agar penyandang disabilitas dapat berpartisipasi secara efektif dan penuh dalam kehidupan politik dan publik secara langsung atau melalui perwakilan;

b. pemerintah dan pemerintah daerah wajib menjamin hak dan kesempatan bagi penyandang disabilitas untuk memilih dan dipilih.

Pemerintah dan Pemerintah Daerah wajib menjamin hak politik penyandang disabilitas dengan memperhatikan keragaman disabilitas dalam pemilihan umum, pemilihan gubernur, bupati/walikota, dan pemilihan kepala desa atau nama lain, termasuk: berpartisipasi langsung untuk ikut dalam kegiatan dalam pemilihan umum, pemilihan gubernur, bupati/walikota, dan pemilihan kepala desa atau nama lain; mendapatkan hak untuk didata sebagai pemilih dalam pemilihan umum, pemilihan gubernur, bupati/walikota, dan pemilihan kepala desa atau nama lain; memastikan bahwa prosedur, fasilitas, dan alat bantu pemilihan bersifat layak, dapat diakses, serta mudah dipahami dan digunakan; melindungi hak penyandang disabilitas untuk memilih secara rahasia tanpa intimidasi; melindungi hak penyandang disabilitas untuk mencalonkan diri dalam pemilihan, untuk memegang jabatan, dan melaksanakan seluruh fungsi publik dalam semua tingkat pemerintahan; menjamin penyandang disabilitas agar dapat memanfaatkan penggunaan teknologi baru untuk membantu pelaksanaan tugas; menjamin kebebasan penyandang disabilitas untuk memilih pendamping sesuai dengan pilihannya sendiri; mendapatkan informasi, sosialisasi, dan simulasi dalam setiap tahapan dalam pemilihan umum, pemilihan gubernur, bupati/walikota, dan pemilihan kepala desa atau nama lain; dan menjamin terpenuhinya hak untuk terlibat sebagai penyelenggara dalam pemilihan umum, pemilihan gubernur, bupati/walikota, dan pemilihan kepala desa atau nama lain (Rahmanto, 2019: 27-28).

Dengan demikian pemenuhan hak politik penyandang disabilitas telah diatur dalam Undang-undang Nomor 8 Tahun 2016, Undang-undang Nomor 7 Tahun 2017 tentang pemilu, selain itu pemerintah dan pemerintah daerah wajib menjamin agar penyandang disabilitas dapat berpartisipasi secara efektif dan penuh dalam kehidupan politik secara langsung atau melalui 
perwakilan. Pemerintah dan pemerintah daerah juga wajib menjamin hak dan kesempatan bagi penyandang disabilitas untuk menilih dan dipilih dalam pemilihan umum.

\section{Tinjauan Fiqh Siyasah Dusturiyah}

Fiqh siyasah merupakan ilmu yang mempelajari tentang urusan umat dan negara dengan hukum, peraturan, dan kebijaksanaannya yang dibuat oleh pemegang kekuasaan yang sejalan dengan dasar-dasar syariat Islam untuk mewujudkan kemaslahatan umat. Dalam fiqh siayasah ada beberapa pembagian bidang, yaitu:

a. Siyasah dusturiyah

Siyasah dusturiyah adalah bagian fiqh siyasah yang membahas tentang masalah perundaang-undangan negara. Bagian ini mencakup kajian tentang penetapan hukum oleh legislatif ( tasyri'iyyah ), peradilan oleh lembaga yudikatif ( qadhaiyyah), dan administrasi pemerintahan oleh birokrasi atau eksekutif (idariyyah ). Disamping itu juga membahas konsep negara hukum dalam siyasah dan hubungan timbal balik antara pemerintah dan warga negara serta hak-hak warga negara yang wajib dilindungi .

Fiqh siyasah dusturiyah ini juga terbagi kedalam beberapa bagian bidang yaitu:

1). Bidang siyasah tasri'iyyah, termasuk di dalamnya persoalan ahlu hali wal aqdi, perwakilan persoalan rakyat. Hubungan muslimin dan non-muslim di dalam suatu negara, sepereti undang-undang dasar, undang-undang, peraturan pelaksana, peraturan daerah.

2). Bidang siyasah tanfidziyah, termasuk di dalamnya persoalan imamah,persoalan bai'ah,wuzarah.waliy al- ahdi.

3). Bidang siyasah qadha'iyah, termasuk di dalamnya masalah-masalah peradilan

4). Bidang siyasahidariyah, termasuk di dalamnya masalah- maslah administrasi dan kepegawaian (Djazuli,2003. Hal 48).

b. Siyasah Dauliyah

Bisa disebut juga politik perundang-undangan. Bagian ini mencakup kajian tentang penetapan hukum oleh legislatif (tasyri'iyyah), peradilan oleh lembaga yudikatif (qadhaiyyah), dan administrasi pemerintahan oleh birokrasi atau eksekutif (idariyyah)

c. Siyasah Maliyah

Membahas tentang politik keuangan dan moneter dan membahas sumber-sumber keuangan negara, pengeluaran dan belanja negara, perdagangan internasional, pajak, dan perbankan.

Melihat pembagian objek kajian di atas, secara lebih khusus pengkajian Terhadap pemenuhan hak politik penyandang disabilitas masuk ke dalam pembahan fiqh siyasah dusturiyah mengkaji tentang mengkaji tentang peraturan perundang-undangan, penetapan hukum oleh lembaga legislatif, peradilan dalam kekuasaan yudikatif, dan pelaksanaan pemerintahan oleh kekuasaan eksekutif dan hubungan timbal balik antara pemerintah dan warga negara serta hak-hak warga negara yang wajib dilindungi. Dalam kajian fiqh siyasah terdapat persoalan mengenai rakyat, statusnya dan hak-haknya.Hak politik warga negara yang dijelaskan dalam islam antara lain:

1). Hak Memilih (Haqqal-Intikhab)

2). Hak untuk Diajak Bermusyawarah (Haqqal-Musyawarat) 3). Hak Mengawasi / Mengontrol (Haqqal-Muraqabat)

4). Hak Menurunkan Khalifah (apabila keadaan mengharuskan) (Haqqal-'Azl) 
5). Hak untuk Mencalonkan (Haqqal-Tarsyih)

6). Hak untuk Dipilih / Memangku Jabatan-jabatan Umum (Haqq Tawalliyal-Wazha-ifal'Ammat)

Hak-hak yang berhak rakyat terima dan miliki adalah perlindungan terhadap hidupnya, harta dan kehormatannya, perlilndungan terhadap kebebasan pribadi, kebebasan menyatakan pendapat dan terjamin kebutuhan pokok hidupnya dengan tidak membedakan suku, ras, agama, termasuk tentang penyandang disabilitas.

Dalam perspektif Islam, penyandang disabilitas identik dengan istilah dzawil âhât, dzawil ihtiyaj al-khashah atau dzawil a'dzâr: orang-orang yang mempunyai keterbatasan, berkebutuhan khusus, atau mempunyai uzur. Nilai-nilai universalitas Islam seperti al-musawa (kesetaraan/equality: Surat Al-Hujurat: 13), al-'adalah (keadilan/justice: Surat An-Nisa: 135 dan Al-Maidah ayat 8), al- hurriyyah (kebebasan/freedom: Surat At-Taubah ayat 105) dan semisalnya.

Sebagaimana Keputusan Muktamar NU Ke-30 tahun 1999 di Kediri menjadi landasan atas penghargaan dan perlindungan terhadap hak-hak penyandang disabilitas sekaligus menegasi sikap dan tindakan diskriminatif terhadap mereka. Islam memandang semua manusia adalah setara. Yang membedakannya adalah tingkat ketakwaannya. Tak terkecuali bagi para penyandang disabilitas. Mereka berhak mendapat perlakuan manusiawi dan layanan fasilitas, fasilitas beribadah, fasilitas pendidikan dan fasilitas dalam Pemilu.

Lebih lanjut Allah menjelaskan dalam surat An-Nur ayat 61:

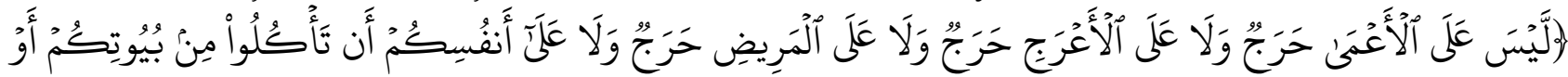

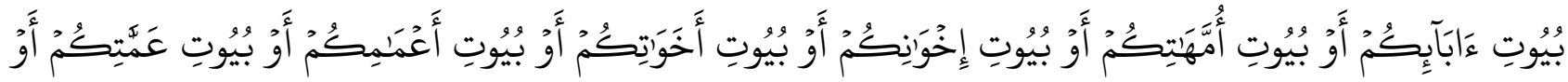

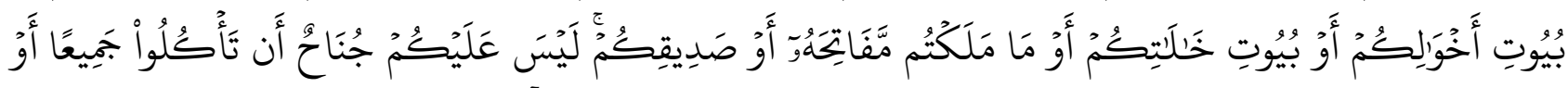

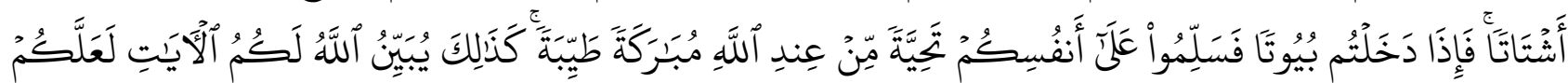

“Tidak ada halangan bagi orang buta, tidak (pula) bagi orang pincang, tidak (pula) bagi orang sakit, dan tidak (pula) bagi dirimu sendiri, makan (bersama-sama mereka) dirumah kamu sendiri atau dirumah bapak-bapakmu, dirumah ibu-ibumu, dirumah saudara-saudaramu yang lakilaki, di rumah saudaramu yang perempuan, dirumah saudara bapakmu yang laki-laki, dirumah saudara bapakmu yang perempuan, dirumah saudara ibumu yang laki-laki, dirumah saudara ibumu yang perempuan, dirumah yang kamu miliki kuncinya atau dirumah kawan-kawanmu. Tidak ada halangan bagi kamu makan bersama-sama mereka atau sendirian. Maka apabila kamu memasuki (suatu rumah dari) rumah-rumah (ini) hendaklah kamu memberi salam kepada (penghuninya yang berarti memberi salam) kepada dirimu sendiri, salam yang ditetapkan dari sisi Allah, yang diberi berkat lagi baik. Demikianlah Allah menjelaskan ayat-ayatnya(Nya) bagimu, agar kamu memahaminya."

Ayat ini secara eksplisit menegaskan kesetaraan sosial antara penyandang disabilitas dan mereka yang bukan penyandang disabilitas. Mereka harus diperlakukan secara sama dan diterima secara tulus, tanpa diskriminasi, dan tanpa stigma negatif dalam kehidupan sosial. Islam sangat memperhatikan penyandang disabilitas, menerimanya secara setara sebagaimana manusia lainnya dan bahkan memprioitaskannya. 
Salah satu sarana yang disediakan oleh pemerintah untuk memenuhi hak-hak politik rakyatnya adalah melalui pemilihan umum (Pemilu). Terkait pemilihan umum undang-undang sudah mengatur tentang tata cara pelaksanaanya, siapa saja yang berhak memilih dan lain sebagainya yang berhubungan dengan terlaksananya pemilihan umum.

Kegiatan pemilihan umum (general election) juga merupakan salah satu sarana penyaluran hak asasi warga negara yang sangat prinsipil. Oleh karena itu, dalam rangka pelaksanaan hakhak asasi warga negara adalah keharusan bagi pemerintah untuk menjamin terlaksananya penyelenggaraan pemilihan umum sesuai dengan jadwal ketatanegaraan yang telah ditentukan.

Sesuai dengan prinsip kedaulatan rakyat di mana rakyatlah yang berdaulat, maka semua aspek penyelenggaraan pemilihan umum itu sendiri harus juga dikembalikan kepada rakyat untuk menentukannya adalah pelanggaran terhadap hak-hak asasi apabila, pemerintah tidak menjamin terselenggaranya pemilihan umum, memperlambat penyelenggaraan pemilihan umum tanpa persetujuan para wakil rakyat, ataupun tidak melakukan apa-apa sehingga pemilihan umum tidak terselenggara sebagaimana mestinya. (Thohah, 2003: 99)

Dalam fiqhsiyasahlembaga yang betugas untuk pemenuhan hak-hak politik rakyat adalah Ahlul Halii Wal Aqdi.Lembaga Ahlul Halii Wal Aqdidalam sejarah pemerintahan Islam khususnya pada masa pemerintahan Khulafaur Rasyidin bisa disebut sebagai panitia penyelenggara pemilihan umum yang meiliki keanggotaan sangat terbatas.

Selain sebagai panitia penyelenggara pemilihan khalifah, lembaga Ahlul Halii Wal Aqdi atau al-syura meiliki tugas dan kewengan untuk memberikan masukan kepada khalifah, sebagai lembaga yang menampung aspirasi masyarakat, melakukan controlling terhadap kebijakankebijakan pemerintah,membuat undang-undang sekaligus mempunyai hak untuk mebatasi jumlah kandidat yang akan menjadi pemimpin. Kajian terhadap AhlulHalii Wal Aqdi memberikan gambaran, bahwa kewenangan Ahlul Halii Wal Aqdi memiliki kesamaan dengan kewenangan Komisi Pemilihan Umum terkait pemenuhan hak politik rakyatnya (Djazuli, 2003: 33).

Jika melihat dari salah satu tugas dan kewengan lembaga Ahlul Halii Wal Aqdi yakni menampung aspirasi rakyat dan terhadap pengangkatan menjadi khalifah tersebut sama dengan tugas KPU yang memiliki tugas dan kewengan untuk menyelenggerakan pemilihan pemimpin, yang nantinya akan dipilih oleh rakyat secara langsung lewat pemilu. Setelah proses pemilihan dilakukan, lembaga Ahlul Halii Wal Aqdi melakukan baiat terhadap khalifah terpilih.

Semua warga negara dijamin hak-hak dasar tertentu. Menurut Subhi Mahmassani dalam bukunya Arkan Huquq al-Insan, beberapa hak warga negara yang perlu dilindungi adalah: jaminan terhadap keamanan pribadi, harga diri dan harta benda, kemerdekaan untuk mengeluarkan pendapat dan berkumpul, hak untuk mendapatkan pelayanan hukum secara adil tanpa diskriminasi, hak untuk mendapatkan pendidikan yang layak, pelayanan medis dan kesehatan, serta keamanan untuk melakukan aktifitas-aktifitas ekonomi.

Pada kenyataannya, penyandang disabilitas tetap merupakan kelompok yang paling rentan dan termarjinalkan dalam masyarakat. Mereka belum mendapatkan hak untuk memperoleh kesempatan dan perlakuan agar bisa bertindak dan beraktivitas sesuai dengan kondisi mereka. Salah satu kesulitan yang dihadapinya dalam bidang politik adalah ketika pelaksanaan pemilihan umum dalam menggunakan hak pilihnya.

Dalam Islam tidak ada halangan bagi umat muslim untuk berkumpul bersama-sama dengan kaum disabilitas, baik di lingkungan rumah maupun di luar rumah. Hal ini menandakan 
dan membuktikan bahwa adanya kesetaraan bagi kaum disabilitas dan menganjurkan pula kepada kita agar tidak membeda-bedakan dan mendiskriminasikan para kaum disabilitas. Kesetaraan sosial antara penyandang disabilitas dan mereka yang bukan penyandang disabilitas. Mereka harus diperlakukan secara sama dan diterima secara tulus tanpa diskriminasi dalam kehidupan sosial.

Jika ditinjau dari segi teori dalam hak-hak berpolitik, hak politik dapat diartikan sebagai suatu kebebasan dalam menentukan pilihan yang tidak dapat diganggu ataupun diambil oleh siapapun dalam kehidupan bermasyarakat di suatu negara. (Saefudin, 1996: 17) Namun faktanya sering ditemukan sebuah ketidakadilan dalam persamaan hak-hak berpolitik, dimana penyandang disabilitas sedikit diberikan kesempatan untuk ikut serta dalam Pemilu. Hak berpolitik dalam Islam menjelaskan semua umat mempunyai hak dalam berpolitik, hal itu berbeda dengan faktanya masih banyak hak politik khususnya penyandang disabilitas yang dikucilkan dan tidak diberi kesempatan yang sama dalam menyelenggarakan politik.

Ketidakadilan hanya akan mengakibatkan terjadinya kerusakan, dimana orang yang salah diberi amanah, sedangkan orang yang benar dituduh sebagai pembuat kerusakan. Ketidakadilan akan semakin mempercepat terjadinya kericuhan, kegaduhan bahkan kehancuran jika dilakukan oleh seorang pemimpin atau penguasa, sementara tidak ada satu pihak pun yang memberikan perimbangan pendapat.

Dapat disimpulkan bahwa pelaksanaan pemenuhan hak politik penyandang dalam pemilu serentak tahun 2019 di Kabupaten Tanah Datar belum sesuai dengan fikihsiyasahdusturiyah. Dalam Islam setiap masyarakat memiliki hak yang sama yang membedakannya hanya ketakwaan mereka kepada Allah SWT. Pada pelaksanaan pemilu serentak tahun 2019 di Kabupaten Tanah Datar masih terjadi diskriminasi terhadap kaum disabilitas yang mana mereka tidak dapat menyalurkan suara/aspirasi mereka dalam pemilihan umum yang mana hal ini tidak sesuai dengan yang telah dijelaskan oleh ajaran Islam.

\section{KESIMPULAN}

Hak politik bagi penyandang disabilitas di Kabupaten Tanah Datar belum terpenuhi secara keseluruhan. Pemilu serentak Tahun 2019 Komisi Pemilihan Umum tidak efektif dalam memberikan pendidikan politik kepada pemilih disabilitas sebagaimana yang dijelaskan dalam Undang-Undang Nomor 8 Tahun 2016 tentang penyandang disabilitas. Adapun kendala yang dihadapi oleh Komisi Pemilihan Umum (KPU) dalam pemenuhan hak politik penyandang disabilitas adalah kesulitan dalam pendataan dikarenakan lokasi tempat tinggal penyandang disabilitas tersebut sulit untuk dijangkau, kesulitan dalam mentransfer materi kepada penyandang disabilitas dan membutuhkan metode khusus untuk menyampaikannya, kesulitan dalam pemberian sosialisasi. Tidak adanya organisasi disabilitas yang dapat dijadikan wadah bagi penyelenggara untuk berhubungan dengan kelompok penyandang disabilitas. Pemenuhan hak politik penyandang disabilitas telah diatur dalam Undang-undang Nomor 8 Tahun 2016, Undang-undang Nomor 7 Tahun 2017 tentang pemilu. Selain itu pemerintah dan pemerintah daerah wajib menjamin agar penyandang disabilitas dapat berpartisipasi secara efektif dan penuh dalam kehidupan politik secara langsung atau melalui perwakilan. Pelaksanaan pemenuhan hak politik pemilih disabilitas dalam pemilu serentak tahun 2019 di Kabupaten Tanah Datar belum sesuai dengan fiqh siyasah dusturiyah. Dalam Islam setiap masyarakat 
memiliki hak yang sama yang membedakannya hanya ketakwaan mereka kepada Allah SWT. Pada pelaksanaan pemilu serentak tahun 2019 di Kabupaten Tanah Datar masih terjadi diskriminasi terhadap kaum disabilitas yang mana mereka tidak dapat menyalurkan aspirasi dalam pemilihan umum. Hal ini tidak sesuai dengan yang telah dijelaskan oleh ajaran Islam.

\section{DAFTAR PUSTAKA}

Djazuli, A. (2004). Figh Siyasah, Implimentasi kemaslahatan Umat dalam Rambu- rambu Syariah. Jakarta: Kencana, 2004.

Halilia, M. R. (2017). Pemenuhan Hak Politik Penyandang Disabilitas Sesuai Dengan Undang-Undang Nomor 8 Tahun 2016 Tentang Penyandang Disabilitas Oleh Komisi Pemilihan Umum Kota Yogyakarta. Supremasi Hukum, 6 (2): 1-24.

Iqbal, M. (2014). Figh Siyasah Kontekstualisasi Doktrin Politik Islam. Jakarta: Kencana.

Pawesti, A. (2017). Hak Penyandang Disabilitas Dalam Perspektif Ham International Dan Ham Nasional. Era Hukum.

Rahmanto, T. Y. (2019). Hak Pilih Bagi Penyandang Disabilitas Mental Ditinjau Dari Perspektif Hak Asasi Manusia. Pusat Penelitian dan Pengembangan Hak Asasi Manusia Badan Penelitian dan Pengembangan Hukum dan Hak Asasi Manusia Kementerian Hukum dan Hak Asasi Manusia RI, 10.

Rita, M. D. (2016). Peran Komisi Pemilihan Umum Dalam Sosialisasi Pemilihan Umum Kepala Daerah Kepada Penyandang Disabilitas Dikota Bandar Lampung. Skripsi tidak diterbitkan. Lampung: Universitas Lampung.

Saefudin, A. M. (1996). Ijtihad Politik Cendikiawan Muslim. Jakarta: Gema Insani Press.

Syaiful, R \& I. R. (2019). Hak Pilih Penyandang Disabilitas dalam Pemilihan Umum di Indonesia. Faculty of Law, 151 (6)

Thohah Miftah. (2003). Birokrasi dan Politik Di Indonesia. Jakarta: PT Raja Grafindo Persada. Undang-Undang Nomor 8 Tahun 2016 